\title{
PILATES EXERCISE DAPAT MENURUNKAN \\ INDEKS MASSA TUBUH (IMT) PEREMPUAN OBESITAS TINGKAT 1 DI PERUMAHAN BUMI DIRGANTARA PERMAI BEKASI
}

\author{
Dwi Agustina, Nikky Novannisa \\ Poltekkes Kemenkes Jakarta III \\ Email:dwiagustinarosadi@gmail.com
}

\begin{abstract}
The prevalence of obesity is tend to increase both in the world and in Indonesia, and a higher prevalence in women. Obesity is a risk factor of various degenerative diseases such as coronary heart disease and stroke, musculoskeletal disorders, especially osteoarthritis, diabetes mellitus and cancer. One exercise that is appropriate for treating obesity is Pilates exercise which is a muscle contraction exercises that are low impact. The aim of this study was to determine the effect of Pilates Exercise on obese level 1 women's body mass index. The type of research was experimental with pre-experimental research design. The experiment was conducted in late April-May 2016 in Bumi Dirgantara Permai. The number of sample was 15 obese level 1women. Pilates exercises was given for one hour three times a week for 5 weeks. Analysis of the data include univariate and bivariate with the Kolmogorov-Smirnov test for checking normality data and Paired t-test for testing IMT different before and after intervention. Results: The mean BMI before intervention was $25.74 \mathrm{~kg} / \mathrm{m} 2$ and after the intervention of $26.44 \mathrm{~kg} / \mathrm{m} 2$. The reduction in BMI of $0.7 \mathrm{~kg} / \mathrm{m} 2$, with test results p value of 0.0001 indicated the difference in IMT before and after the intervention were significant. Conclusion:To maintain the IMT and improve posture, Pilates Exercise should be done regularly.
\end{abstract}

Keywords: Pilates Exercise, Obesity

\section{ABSTRAK}

Prevalensi obesitas cenderung meningkat baik di dunia, maupun di Indonesia, dan prevalensi pada wanita lebih tinggi. Obesitas merupakan faktor risiko dari berbagai penyakit degeneratif seperti jantung koroner dan stroke, kelainan musculoskeletal khususnya osteoatritis, diabetes mellitus dan kanker. Salah satu latihan yang sesuai untuk mengatasi obesitas adalah Pilates exercise yang merupakan latihan kontraksi otot yang bersifat low impact. Penelitian ini bertujuan adalah untuk mengetahui pengaruh Pilates Exercise terhadap indeks massa tubuh pada perempuan obesitas tingkat 1. Jenis Penelitian yang digunakan adalah penelitian eksperimental dengan desain penelitian pra-eksperimental. Penelitian dilaksanakan pada akhir April - Mei 2016 di Bumi Dirgantara Permai. Besar sampel 15 orang perempuan obesitas tingkat 1. Latihan pilates diberikan selama 1 jam 3 kali seminggu dalam 5 minggu. Analisa data meliputi univariat dan bivariat dengan uji Kolmogorov-Smirnov untuk normalitas data dan Paired t-test untuk uji beda IMT sebelum dan sesudah intervensi. Hasil: Rerata IMT sebelum intervensi adalah $25,74 \mathrm{~kg} / \mathrm{m} 2$ dan setelah intervensi $26.44 \mathrm{~kg} / \mathrm{m} 2$. Penurunan IMT $0.7 \mathrm{~kg} / \mathrm{m} 2$, dengan hasil uji nilai p sebesar 0.0001 menunjukkan adanya perbedaan IMT sebelum dan sesudah intervensi yang signifikan. Untuk menjaga IMT dan memperbaiki postur tubuh, sebaiknya melakukan Pilates Exercise secara teratur.

Kata Kunci: Pilates Exercise, Obesitas 


\section{PENDAHULUAN}

Kemajuan ilmu dan teknologi mempercepat inovasi pengembangan peralatan mutakhir yang mempermudah pekerjaan manuasia. Sejak revolusi industry, berbagai kegiatan yang semula harus dilakukan secara manual, saat ini digantikan oleh mesin yang menghemat tenaga manusia. Kemajuan tekhnologi seperti dua mata pisau yang tidak hanya memiliki pengaruh positif tapi juga membuat manusia menjadi tidak aktif yang berdampak negatif terhadap kesehatan manusia (Hallal 2012).

Menurut WHO tingkat ketidak aktifan fisik meningkat di seluruh dunia (WHO 2010). Hal yang sama juga dinyatakan oleh Hallal (2012) yang memprediksi proporsi ketidak aktifan fisik pada manusia dewasa di dunia adalah sekitar $31,2 \%$, dan perempuan lebih banyak yang tidak aktif dibandingkan laki-laki.

Di Indonesia proporsi penduduk berusia $>10$ tahun yang tidak aktif adalah sebesar 26.1\% (Kementerian Kesehatan 2013).

Ketidak aktifan fisik merupakan faktor risiko untuk kegemukan dan obesitas (WHO 2010). Pada tahun 2014, prevalensi kegemukan di dunia pada orang dewasa berkisar 39\%, dan pada perempuan lebih tinggi dari laki-laki yaitu $40 \%$ sedangkan laki-laki hanya
$38 \%$. Proporsi obesitas juga menunjukkan perempuan lebih tinggi dari lakilaki yaitu 15\% dan laki-laki $11 \%$ dengan rata-rata 13\% (WHO 2016).

Di Indonesia prevalensi obesitas juga tinggi dengan kecenderungan yang sama. Prevalensi obesitas pada perempuan dewasa hampir 2 kali lipat yaitu $32,9 \%$ dibandingkan dengan lakilaki yang hanya $19,7 \%$, dan Jawa Barat merupakan salah satu propinsi yang prevalensinya di atas rata-rata nasional (Kementerian Kesehatan 2013).

Metode yang digunakan untuk menentukan seseorang menderita obesitas adalah antropometri dengan menggunakan Indeks Massa Tubuh (IMT), salah satu metode yang umum digunakan di masyarakat karena cepat, mudah dan murah (Widiantini 2014). Seseorang dikatakan gemuk jika IMT $\geq$ $25 \%$, sedangkan obesitas jika IMT $\geq$ 30\% (WHO 2016).

Kegemukan dan obesitas merupakan faktor risiko dari berbagai penyakit degeneratif seperti penyakit kardiovaskular terutama jantung koroner dan stroke, kelainan musculoskeletal khususnya osteoatritis, diabetes mellitus dan kanker. Risiko penyakit degenerative meningkat seiring dengan peningkatan IMT (WHO 2016 \& Kementerian Kesehatan RI 2011). 
Faktor risiko kegemukan dan obesitas meliputi usia, jenis kelamin, tingkat pendidikan, pengetahuan dan sikap, genetik, stress, konsumsi makanan dan aktivitas fisik (Hendra 2016 \& Widiantini 2014). Penyebab utama kegemukan dan obesitas adalah faktor lingkungan yang mengakibatkan ketidakseimbangan antara konsumsi kalori dan pengeluaran energy (WHO 2016 \& Kementerian Kesehatan RI 2011). Pengaruh faktor lingkungan terjadi karena perubahan konsumsi makanan yang mengakibatkan meningkatnya asupan kalori dari makanan tinggi lemak diikuti dengan meningkatnya gaya hidup sedentary sebagai dampak dari kemajuan teknologi yang membuat aktifitas fisik manusia semakin berkurang (WHO 2016 \& Kementerian Kesehatan RI 2011).

Aktivitas fisik memiliki peran yang sangat penting tidak saja dalam mengontrol berat badan tapi juga terhadap status kesehatan secara umum (Warburton 2006). Untuk menjaga kesehatan jantung dan paru pada orang dewasa aktivitas fisik yang direkomendasikan WHO (2010) adalah minimal 150 menit dalam seminggu untuk aktivitas fisik sedang atau 60 menit untuk aktifitas berat dalam seminggu, atau kombinasi dari keduanya sampai mencapai $600 \mathrm{MET} /$ minggu, dan setiap kali malakukan aktifitas fisik, baik sedang atau berat minimal 10 menit.

Aktivitas fisik tidak sama dengan olah raga, meskipun olah raga adalah bagian dari aktivitas fisik. Aktivitas fisik adalah semua gerakan tubuh yang dihasilkan oleh otot skeletal yang membutuhkan pengeluaran energi. Aktivitas fisik adalah semua kegiatan yang dilakukan sehari-hari yang melibatkan gerakan tubuh termasuk olah raga (WHO n.d.). Pada kenyataanya sangat sulit untuk memenuhi aktivitas fisik minimal yang direkomendasikan oleh WHO (2010) tanpa dibarengi dengan olah raga. Untuk individu dengan kegemukan atau obesitas, maka aktivitas fsik yang dilakukan harus lebih banyak agar semakin banyak kalori yang hilang, dan hal tersebut akan sulit dicapai tanpa olah raga (Jakicic 2009).

Olah raga secara teratur berkontribusi dalam menjaga keseimbangan energy. Setiap kegiatan yang melibatkan gerakan tubuh berhubungan dengan pengeluaran energy, semakin tinggi intensitas dan durasi aktivitas fisik, semakin banyak pula energy yang dipakai. Selain itu olah raga juga meningkatkan masa otot, dan pembuluh kapiler yang meningkatkan tingkat 
basal metabolisme, serta konsumsi oksigen yang berarti meningkat pula penggunaan energi (Gross, 2013).

Untuk individu dengan kegemukan atau obesitas, olah raga dengan intensitas tinggi tidak tepat dan sulit untuk dilakukan karena berat badan berlebihan akan menimbulkan masalah mekanikal seperti nyeri sendi dan otot selama melakukan latihan (Amirsasan 2015). Dengan demikian olah raga yang cocok adalah aerobik dengan intensitas rendah namun durasinya lebih lama (Gross 2013 \& Schmidt 2016).

Pilates exercise merupakan salah satu olah raga yang sesuai untuk kegemukan dan obesitas. Pilates merupakan latihan body-mind dengan fokus utama pada pengendalian gerakan, postur dan pernafasan (Shah 2013). Olah raga ini merupakan latihan low impact untuk memperkuat dan menstabilkan core otot tubuh melalui serangkaian gerakan kontraksi otot dan pernafasan untuk memperkuat otot abdomen, pinggang dan punggung termasuk kaki dan tangan (Çakmakç 2012 \& Kim 2014).

Menurut Shah (2013) metode Pilates menggabungkan prinsip latihan dari budaya timur (pengendalian gerakan melalui pikiran, presisi, dan pusat raga sebagai titik energi utama, pengaturan pernafasan dan relaksasi, seperti pada yoga) dan budaya barat (latihan daya tahan, stabilitas, seperti pada balet).

Pilates memiliki banyak manfaat selain untuk penguatan pada otot core, latihan ini juga bermanfaat untuk mengatur pernafasan, melancarkan peredaran darah, serta membangun komposisi massa otot menjadi lebih padat dan tanpa lemak (Shah, 2013). Pilates populer dikalangan perempuan karena memiliki efek terhadap masa tubuh, lingkar pinggang dan komposisi tubuh (Çakmakç 2012).

Penelitian Çakmakç (2012) yang memberikan intervensi Pilates yang dilakukan selama satu jam tiga kali seminggu dalam 10 minggu pada perempuan, berdampak pada penurun berat badan dan prosentasi lemak tubuh, Indeks Masa Tubuh (IMT) serta parameter komposisi tubuh lainnya. Penelitian lainnya pada perempuan perimenapouse, menemukan pilates dapat menurunkan berat badan dan parameter komposisi tubuh (Arslan 2012).

Berdasarkan uraian di atas, penulis merasa tertarik untuk melakukan penelitian dengan judul "Pengaruh Pilates Exercise terhadap Indeks Massa Tubuh pada Perempuan Obesitas Tingkat 1 di Perumahan Bumi Dirgantara Permai Bekasi”. 


\section{METODE}

Jenis penelitian yang digunakan adalah eksperimental, dengan rancangan pra ekperimen yaitu penelitian yang memberikan perlakuan pilates exercise pada 1 kelompok tanpa kelompok pembanding atau kontrol. Pengumpulan data dilakukan dari akhir bulan April sampai dengan akhir bulan Mei 2016 di Perumahan Bumi Dirgantara Permai Bekasi. Populasi dalam penelitian ini adalah semua perempuan berusia 25-50 tahun yang berada di Perumahan Bumi Dirgantara Permai Bekasi, sedangkan sampel adalah bagian dari populasi yang memenuhi kriteria inklusi dan eksklusi serta dianggap mewakili seluruh populasi (Notoatmodojo, 2012). Adapun kriteria inklusi adalah responden tergolong dalam obesitas tingkat $1(\mathrm{IMT}=25,0-29,9 \mathrm{~kg} / \mathrm{m} 2)$ dan bersedia menerima intervensi secara rutin selama 2 bulan. Sedangkan kriteria eksklusi adalah responden memiliki resiko gangguan kesehatan yang mengganggu kegiatan penelitian dan mengikuti intervensi lain selain Pilates Exercise. Besar sampel adalah 15 orang yang dipilih dengan menggunakan metode purposive sampling, yaitu dengan memperhatikan kriteria inklusi dan eksklusi.

Variabel dalam penelitian ini terdiri atas satu variabel bebas (independent variable) dan satu variabel terikat (dependent variable). Variabel Bebas dalam penelitian ini adalah pilates exercise, sedangkan variable terikat adalah IMT.

Metode yang digunakan dalam pengumpulan data adalah wawancara dan antropometri dengan indeks IMT. Wawancara digunakan untuk mendapatkan data demografi responden sedangkan antropometri, untuk mendapatkan data IMT. Instrumen pengumpulan data meliputi kuesioner data demografi, timbangan berat badan untuk mengukur berat badan dan microtoa yang digunakan untuk mengukur tinggi badan. Untuk melaksanakan Pilates exercises digunakan matras dan tikar sebagai alas dan CD player dan speaker yang digunakan sebagai alat untuk memutar memutar musik sebagai pengiring gerakan pilates exercise selama 1 jam.

Intervensi pilates exercise diberikan selama 60 menit setiap sesinya 3 kali seminggu dalam 5 minggu. Setiap sesi latihan terdiri dari 15 menit pemanasan, 35 menit gerakan inti dan 10 menit pendinginan. Gerakan pemanasan dilakukan dengan 5 kali repetisi dalam 2 set yang terdiri dari cat stretch, hundred, shoulder bridge, single leg circle, swimming, single leg stretch, double leg stretch. Gerakan inti dilakukan 8 kali repetisi dalam 2 set 
yang terdiri the saw, roll up, spine stretch, leg pull front, leg pull back, side kick front, double leg kick, hip circle prep. Gerakan pendinginan yang dilakukan masing-masing 4 kali.

Sebelum diberikan intervensi pilates exercise semua responden diukur dulu IMTnya dan setelah dilakukan intervensi selama 5 minggu, dilakukan lagi pengukuran IMT.

Pengolahan dan analisis data dilakukan dengan menggunakan perangkat lunak program pengolah data. Analisis data yang dilakukan meliputi analisis univariat dan bivariat. Analisis univariat menggunakan nilai distribusi frekuensi, mean atau rata-rata, median dan standar deviasi. Sedangkan analisis bivariat dilakukan dengan uji paired t-test, karena berdasarkan uji normalitas dengan Kolmogorov Smirnov diketahui data terdistribusi normal (Hastono 2006).

Penelitian ini dilaksanakan dengan mempertimbangkan prinsip etika penelitian kesehatan yeng meliputi menghargai harkat dan martabat manusia, bermanfaat dan tidak merugikan serta kedilan bagi responden. Proposal penelitian ini telah mendapatkan persetujuan dari Komisi Etik Penelitian Kesehatan Poltekkes Kemenkes Jakarta III pada tanggal 25
April 2016 dengan no. 014/ KEPKPKKJ3/04/2016.

\section{HASIL DAN PEMBAHASAN}

Penelitian ini dilaksanakan selama 3 kali seminggu dalam 5 minggu. Secara keseluruhan, jumlah responden yang mengikuti Pilates Exercise ini berjumlah 15 orang yang semuanya adalah ibu rumah tangga. Responden berusia sekitar 35-50 tahun dengan usia rata-rata 42,60 tahun dan standar deviasi 5,054 tahun. Berdasarkan uji estimasi, didapatkan bahwa 95\% dipercaya usia responden berkisar 39,801-45.399 tahun tahun. Untuk lebih jelasnya dapat dilihat pada tabel 1 berikut ini:

Tabel 1. Distribusi Usia Responden di Perumahan Bumi Dirgantara Permai

\begin{tabular}{|c|c|c|c|}
\hline \multicolumn{4}{|c|}{ Bekasi Tahun 2016} \\
\hline Mean Median & $\mathrm{SD}$ & $\begin{array}{l}\text { Min- } \\
\text { Max }\end{array}$ & $95 \% \mathrm{CI}$ \\
\hline 42,6 & 5,054 & $35-50$ & $\begin{array}{c}39,801- \\
45.399\end{array}$ \\
\hline
\end{tabular}

Berdasarkan kelompok usia, sebagian besar responden berusia 35-39 tahun dengan persentase $33 \%$, sedangkan yang terendah adalah kelompok usia adalah 50-54 tahun dengan persentase $13 \%$, seperti pada gambar 1 berikut ini:

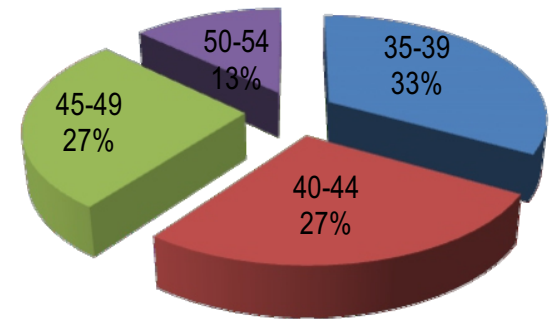

Gambar 1. Distribusi Frekuensi Responden Menurut Kelompok Usia di Perumahan Bumi Dirgantara Permai Bekasi Tahun 2016 
Hasil pengukuran IMT responden sebelum dilakukan intervensi dengan pilates exercise menunjukkan reratanya adalah $26.44 \mathrm{~kg} / \mathrm{m} 2$ dengan standar deviasi 1.66 dan nilai tengah 25.39 $\mathrm{kg} / \mathrm{m} 2$. IMT tertinggi adalah 29.24 $\mathrm{kg} / \mathrm{m} 2$ sedangkan hasil terendah adalah $25.00 \mathrm{~kg} / \mathrm{m} 2$. Berdasarkan uji estimasi, didapatkan bahwa 95\% diyakini ratarata IMT responden sebelum perlakuan berkisar antara $25.52 \mathrm{~kg} / \mathrm{m} 2$ sampai dengan $27.37 \mathrm{~kg} / \mathrm{m} 2$, seperti pada tabel 2 berikut ini:

Tabel 2. Distribusi IMT Responden Sebelum Intervensi di Perumahan Bumi Dirgantara Permai Bekasi Tahun 2016

\begin{tabular}{|c|c|c|c|c|}
\hline Mean & Median & SD & Min-Max & $95 \% \mathrm{CI}$ \\
\hline \multicolumn{5}{|c|}{ Sebelum } \\
\hline 26,44 & 25,39 & 1,66 & $25,0 \quad 29,24$ & $\begin{array}{c}39,80- \\
45.39\end{array}$ \\
\hline
\end{tabular}

Tabel 3 di atas, menunjukkan IMT responden tergolong dalam obesitas tingkat 1 yang sesuai dengan kriteria inklusi pada penelitian ini. IMT merupakan indeks sederhana berat badan menurut tinggi badan yang umum digunakan untuk menilai kekurangan atau kelebihan berat badan. IMT didapatkan dengan menghitung berat badan (dalam $\mathrm{kg}$ ) dibagi dengan tinggi (dalam meter) kuadrat. Nilai IMT tidak tergantung pada jenis kelamin artinya standar yang digunakan untuk laki-laki dan perempuan sama (WHO 2006).
Klasifikasi IMT untuk Asia pasifik menurut WHO (2000) adalah kurus dengan IMT $<18,5 \mathrm{~kg} / \mathrm{m}^{2}$, normal $18,5-22,9 \mathrm{~kg} / \mathrm{m}^{2}$, gemuk $23,0-24,9$ $\mathrm{kg} / \mathrm{m}^{2}$, obesitas tingkat $125,0-29,9$ $\mathrm{kg} / \mathrm{m}^{2}$, obesitas tingkat $2>30 \mathrm{~kg} / \mathrm{m}^{2}$. Untuk lebih jelasnya dapat dilihat pada tabel 3 sebagai berikut:

Tabel 3. Klasifikasi IMT Menurut Kriteria Asia Pasifik

\begin{tabular}{ll}
\hline Klasifikasi & $\mathrm{BMI}\left(\mathrm{kg} / \mathrm{m}^{2}\right)$ \\
\hline Kurus & $<18,5$ \\
\hline Normal & $18,5-22,9$ \\
\hline Gemuk & $23,0-24,9$ \\
\hline Obesitas tingkat 1 & $25,0-29,9$ \\
\hline Obesitas tingkat II & $>30,0$ \\
\hline
\end{tabular}

Setelah mendapat intervensi pilates exercise selama 5 minggu IMT responden secara umum berkurang. Hal ini terlihat dari menurunnya rerata IMT menjadi sebesar $25.74 \mathrm{~kg} / \mathrm{m} 2$ dengan standar deviasi 1.59 dan nilai tengah $25.00 \mathrm{~kg} / \mathrm{m} 2$. Adapun, IMT tertinggi adalah $28.44 \mathrm{~kg} / \mathrm{m} 2$ sedangkan terendah adalah $24.03 \mathrm{~kg} / \mathrm{m} 2$. Berdasarkan uji estimasi, rerata IMT responden setelah perlakuan dipercaya $95 \%$ berkisar antara $24.85 \mathrm{~kg} / \mathrm{m} 2 \mathrm{~s} / \mathrm{d} 26.63 \mathrm{~kg} / \mathrm{m} 2$, sperti pada tabel 4 berikut ini:

Tabel 4. Distribusi IMT Responden Sebelum dan Sesudah Intervensi di Perumahan Bumi Dirgantara Permai Bekasi Tahun 2016

\begin{tabular}{lcccc}
\hline Mean & Median & SD & Min-Max & $95 \%$ CI \\
\hline \multicolumn{4}{c}{ Sesudah } \\
\hline 25,74 & 25,00 & 1,59 & 24,03 & $24,85-26,63$ \\
& \multicolumn{4}{c}{28,44} \\
\hline
\end{tabular}


Perbandingan IMT sebelum dan sesudah intervensi pada gambar 2, memperlihatkan dengan jelas hampir semua responden mengalami penurunan IMT setelah diintervensi dengan pilates exercise selama 5 minggu. Rerata perbedaan IMT sebelum dan setelah intervensi adalah $-0.70 \mathrm{~kg} / \mathrm{m} 2$ dengan standar deviasi -0.52 dan nilai tengah $0.80 \mathrm{~kg} / \mathrm{m} 2$. Perbedaan IMT tertinggi adalah $0.87 \mathrm{~kg} / \mathrm{m} 2$ sedangkan yang terendah adalah $-1.25 \mathrm{~kg} / \mathrm{m} 2$. Uji estimasi menunjukkan bahwa 95\% diyakini selisih rerata IMT responden berkisar antara $-0.99 \mathrm{~kg} / \mathrm{m} 2$ sampai dengan $-0.41 \mathrm{~kg} / \mathrm{m} 2$. Untuk lebih jelasnya dapat dilihat pada tabel 5 berikut ini:

Tabel 5 Distribusi Perbedaan IMT

Responden Sebelum dan Sesudah Intervensi di Perumahan Bumi Dirgantara Permai Bekasi Tahun 2016

\begin{tabular}{ccccc}
\hline Mean & Median & SD & Min-Max & $95 \%$ CI \\
\hline-0.70 & -0.80 & -0.52 & $-1.25-0.87$ & $-0.99--0.41$
\end{tabular}

Selanjutnya untuk menentukan apakah perbedaan IMT sebelum dan sesudah intervensi bermakna secara statistik atau hanya terjadi secara kebetulan dilakukan analisa bivariat dengan menggunakan uji paired T test. Uji ini dipilih karena hasil uji Kolmogorov Smirnov pada tabel 6 memperlihatkan nilai $\mathrm{p}>0,05$ baik untuk IMT sebelum maupun sesudah intervensi, hal ini berarti sebaran kedua data tersebut normal (Hastono 2006).

Tabel 6 Hasil Uji Normalitas Data IMT Sebelum dan Sesudah Intervensi dengan Uji Kolmogorov

\begin{tabular}{lcccc}
\hline IMT & Mean & SD & Nilai p & Keterangan \\
\hline Sebelum & 26,44 & 1,66 & 0,222 & Normal \\
\hline Sesudah & 25,74 & 1,59 & 0,192 & Normal \\
\hline
\end{tabular}

Hasil uji Paired t-test untuk menguji perbedaan IMT sebelum dan sesudah intervensi dapat dilihat pada gambar 2 dan tabel 7 berikut ini:

Tabel 7. Hasil Uji Beda IMT Sebelum dan Sesudah Intervensi dengan Pared $T$ Test

\begin{tabular}{|c|c|c|c|c|}
\hline \multicolumn{5}{|c|}{ Test } \\
\hline Mean & SD & SE & $\begin{array}{c}95 \% \text { CI } \\
\text { Lower Upper }\end{array}$ & Sig (2-tailed) \\
\hline & 0.52 & .13 & 0.99 & 0.0001 \\
\hline
\end{tabular}




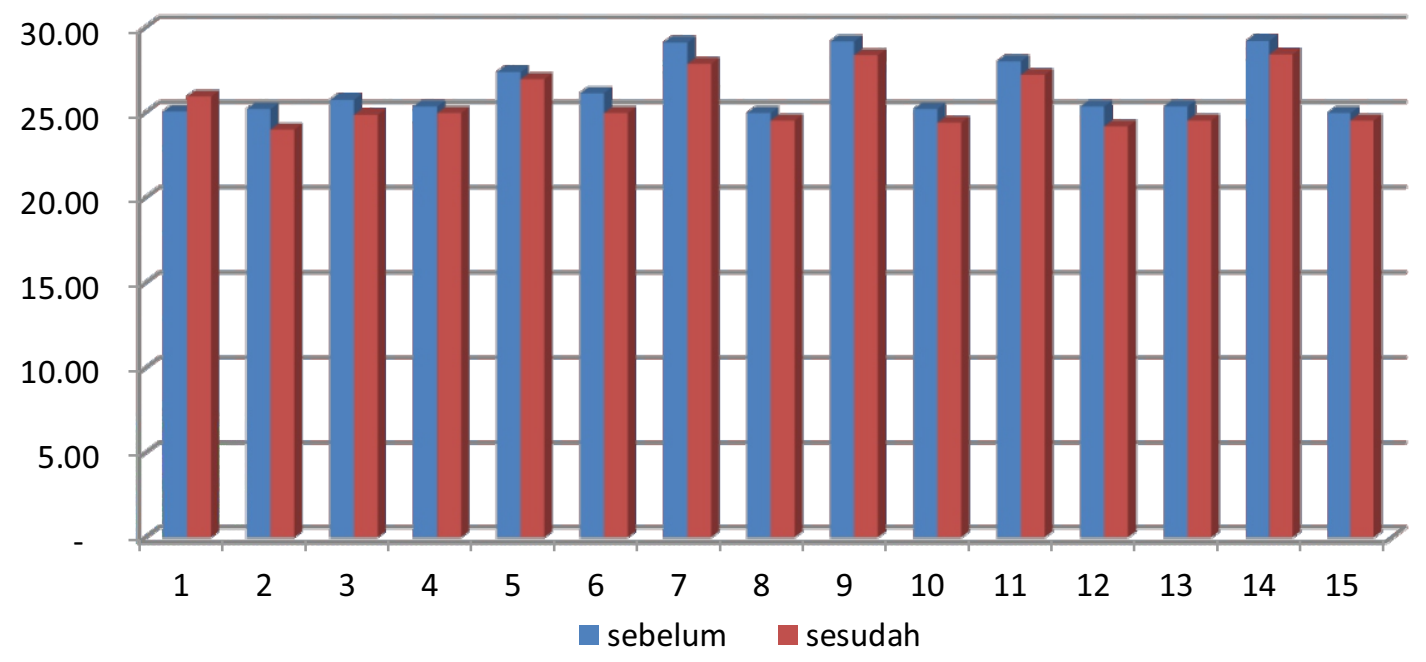

Gambar 2

Perbandingan IMT Responden Sebelum dan Setelah Intervensi di Perumahan Bumi Dirgantara Permai Bekasi Tahun 2016

Berdasarkan tabel 7 terlihat uji Paired ttest menghasilkan p-value sebesar $0.0001>\alpha(0.05)$ yang berarti secara statistic terdapat perbedaan yang bermakna rerata IMT sebelum dan setelah intervensi. Dengan demikian dapat disimpulkan bahwa Pilates Exercise berpengaruh terhadap IMT.

Pilates merupakan latihan yang menggunakan metoda komprehensiv peregangan dan penguatan otot dengan tujuan membangun tubuh yang kuat dengan filosofi pengendalian pikiran atas raga (Aladro-Gonzalvo et al. 2012). Prinsip latihan pilates menekankan peningkatan pernapasan, konsentrasi, kontrol, elongasi aksial dan fleksibilitas yang bertujuan untuk meningkatkan kekuatan (Pestana et al. 2016). Kunci utama dari gerakan pada latihan pilates adalah pengendalian kecepatan, penekanan kualitas dan presisi gerakan (Amirsasan 2015).

Latihan pilates memiliki intensitas rendah jika dibandingkan dengan senam aerobic lainnya (Arslanoğlu \& Şenel 2013), meskipun demikian pada penelitian ini 95\% dipercaya dapat mengurangi IMT pada wanita obesitas tingkat I. Asumsi penulis, menurunnya IMT kemungkinan terjadi karena terjadinya pembakaran kalori selama latihan berlangsung. Menurut Stout (2012) konsumsi energy dapat diukur atau diprediski secara tidak langsung melalui detak jantung. Menurut Pestana (2016) konsumsi energi yang besar tidak hanya terjadi pada latihan aerobik, tetapi juga termasuk latihan postur tubuh yang melibatkan kelompok otot, baik secara terus menerus atau dengan selang waktu tertentu, statis atau dinamis. Selama latihan ekstrimitas dan 
pada saat otot statis, terjadi denyut jantung yang lebih tinggi. Intervensi latihan pilates yang diberikan dalam penelitian ini meliputi kontraksi otot abdominal oblique, transverse abdominal, pelvic floor, multifidus dan stabilitas shoulder girdle, yang mengeluarkan banyak energy. Selain itu latihan pernafasan yang dilakukan dalam pilates dapat meningkatkan konsumsi energy, karena selain otot aktif, otot yang terlibat dalam pernafasan juga mengkonsumsi banyak energi. Latihan pernafasan juga menyebabkan pengiriman oksigen ke otot menjadi lebih baik. Peneltian yang dilakukan oleh Amirsasan (2015), menunjukkan pernafasan dalam dan pengiriman oksigen meningkatkan sensitivitas insulin dan juga meningkatkan transport glukosa ke otot (GLUT4) yang mengakibatkan peningkatan oksidasi lemak dalam tubuh sehingga mengurangi kandungan lemak dan masa lemak tubuh.

Banyak penelitian yang telah dilakukan, mendukung hasil dari penelitian ini. Penelitian Çakmakç (2012) pada perempuan gemuk di Turki, dengan dengan memberikan pilates selama 60 menit 3 kali seminggu dalam 10 minggu mendapatkan hasil yang signifikan terhadap penurunan IMT. Penelitian lain yang dilakukan oleh Arslan pada tahun 2012 pada wanita perimenapouse dengan gaya hidup sedentary juga memberikan hasil serupa. Penelitian tersebut memberikan intervensi pilates selama 6 minggu dengan dengan durasi 60 menit 3 kali seminggu dengan hasil adanya penurunan rerata IMT yang signifikan secara statistik. Penelitian yang dilakukan Pestana (2016) yang membandingkan pengaruh latihan pilates dan latihan resisten terhadap IMT juga mendukung penelitian ini. Pada penelitian tersebut, latihan pilates secara statistic menunjukkan lebih efektif dalam menurunkan IMT dibandingkan dengan latihan resisten.

Keterbatasan dalam penelitian ini adalah peneliti tidak sepenuhnya dapat mengontrol faktor lain yang mempengaruhi IMT yaitu asupan gizi meskipun peneliti secara terus menerus sudah mengingatkan kepada responden.

\section{SIMPULAN}

Berdasarkan uraian di atas dapat disimpulkan bahwa dengan pemberian Pilates Exercise selama 1 jam 3 kali dalam 5 minggu secara signifikan dapat menurunkan IMT sebesar $0.7 \mathrm{~kg} / \mathrm{m} 2$ pada perempuan obesitas tingkat 1 . Untuk menjaga berat badan tubuh yang ideal, sebaiknya melakukan latihan pilates secara teratur. Latihan pilates yang dilakukan secara konsisten tidak saja akan mejaga berat badan tubuh tapi 
juga memperbaiki postur tubuh yang dapat meningkatkan rasa percaya diri tidak saja untuk perempuan tapi juga laki-laki. Selain itu, pilates exercise juga dapat meningkatkan kekuatan dan kelenturan otot tubuh yang sangat dibutuhkan dalam melakukan berbagai aktifitas rutin sehari-hari.

\section{DAFTAR RUJUKAN}

Aladro-Gonzalvo, A.R. et al., 2012. The Effect Of Pilates Exercises on Body Composition: A Systematic Review. Journal of Bodywork and Movement Therapies, 2012(1), pp.109-114.

Amirsasan, R. \& Dolgarisharaf, R., 2015. Pilates Training Preventive Effects of Metabolic Syndrome in Sedentary Overweight Females. International Journal of Sport Studies, 5(5), pp.596-602.

Arslan, F. et al., 2012. Evaluation of The Effects of Pilates Mat Exercise Program on Some Fitness Parameters and Weight Loss of Middle Aged Perimenopausal Sedentary Women. Journal of Physical Education And Sport Sciences, 6(1).

Arslanoğlu, E. \& Şenel, Ö., 2013. Effects of Pilates Training on Some Physiological Parameters and Cardiovascular Risk Factors of Middle Aged Sedentary Women. International Journal of Sport Studies, 3(2), pp.122-129.

Çakmakç, E., 2012. The Effect Of 10 Week Pilates Mat Exercise Program on Weight Loss and Body
Composition for Overweight Turkish Women. World Applied Sciences Journal, 19(3), pp.431438.

González-Gross, M. \& Meléndez, A., 2013. Sedentarism, Active Lifestyle and Sport: Impact on Health Aand Obesity Prevention. Nutricion Hospitalaria, 28(5), pp.89-98.

Hallal P.C. et al., 2012. Global Physical Activity Levels: Surveillance Progress, Pitfalls, and Prospects. The Lancet, 380(9838), pp.247257. Available at: http://dx.doi.org/10.1016/S0140$\underline{6736(12) 60646-1}$

Hastono, S.P., 2006. Analisis Data, Jakarta: FKM UI.

Hendra, C. et al., 2016. Faktor-Faktor Risiko terhadap Obesitas pada Remaja di Kota Bitung. Journal e Biomedik (aBm), 4(1). Available at: chrome-extension://mhjfbmdgcfjbb paeojofohoefgiehjai/index.html.

Jakicic, J.M., 2009. The Effect Of Physical Activity on Body Weight. Obesity, 17 Suppl 3(n3s), pp.S34-8. Available at: http://www.ncbi.nlm. nih.gov/entrez/query.fcgi?cmd=Ret rieve $\& \mathrm{db}=\mathrm{PubMed} \& d o p \mathrm{t}=$ Citation \&list uids $=19927144$.

Kementerian Kesehatan, 2013. Riset Kesehatan Dasar : Riskesdas 2013, Jakarta: Badan Penelitian dan Pengembangan Kesehatan.

Kementerian Kesehatan RI, 2011. Pedoman Pencegahan dan Penanggulangan Kegemukan dan Obesitas pada Anak Sekolah, Jakarta: Direktorat Bina Gizi 
Kesehatan Ibu dan Anak Kementerian Kesehatan RI. Available at: chromeextension://mhjfbmdgcfjbbpaeojofo hoefgiehjai/index.html.

Kim, H.-J., Kim, J. \& Kim, C.-S., 2014. The Effects of Pilates Exercise on Lipid Metabolism and Inflammatory Cytokines $m R N A$ Expression in Female Undergraduates. Journal of Exercise Nutrition \& Biochemistry, 18(3), pp.267-275. Available at: http://dx.doi.org/10.5717/jenb.2014 .18.3.267.

Notoatmodjo, Soekidjo., 2012. Metodologi penelitian kesehatan. Jakarta: PT Rineka Cipta

Pestana, M.D.S. et al., 2016. Pilates Versus Resistance Exercise on The Serum Levels of $\mathrm{Hs}_{\mathrm{s}} \mathrm{CRP}$, in The Abdominal Circumference and Body Mass Index (BMI) in Elderly Individuals. Journal Motricidade, 12(1), pp.128-140. Available at: http://dx.doi.org/10.6063/motricida de. 6682 .

Schmidt, S., 2016. Obesity and Exercise. American College of Sports Medicine. Available at: http://www.acsm.org/publicinformation/articles/2016/10/07/obe sity-and-exercise [Accessed February 19, 2017].

Shah, S., 2013. Pilates Exercises. International Journal of Physiotherapy and Research, 1(4), pp.196-203. Available at: www.ijmhr.org/ijpr.html.
Stout, Jean L. 2012. Phisical Fitnes During Childhood an Adolescence dalam Physical Therapy for Children. Missouri: Elsevier Saunder.

Warburton, D.E.R., 2006. Health Benefits of Physical Activity: The Evidence. Canadian Medical Association Journal, 174(6), pp.801-809. Available at: http://www.cmaj.ca/cgi/doi/10.150 3/cmaj.051351.

WHO, 2006. BMI Classification. Available at: http://apps.who.int/bmi/index.jsp?i ntroPage=intro_3.html.

WHO, 2010. Global Recommendations on Physical Activity for Health. Geneva: WHO.

WHO, 2016. Obesity and Overweight. Available at: http://www.who.int/ mediacentre/factsheets/fs311/en/ [Accessed January 15, 2017].

WHO, Physical Activity. Available at: http://www.who.int/dietphysicalacti vity/pa/en/ [Accessed January 20, 2017].

WHO, 2000. The Asia Pacific Perspective: Redefining Obesity and Its Treatment, Geneva: WHO.

Widiantini, W. \& Zarfiel, T., 2014. Aktivitas Fisik, Stres, dan Obesitas pada Pegawai Negeri Sipil. Jurnal Kesehatan Masyarakat Nasional, 8(7). Available at: http://journal.fkm.ui.ac.id/kesmas/a rticle/view/374/373. 